\title{
DE NINGUÉM A OUTREM: DIALÉTICA E MIMESE, JUDAÍSMO E HUMANISMO A PARTIR DE BLANCHOT E ADORNO
}

\author{
João Wilson Sobral Santos ${ }^{1}$ \\ Universidade do Estado do Rio de Janeiro (UERJ) \\ https://orcid.org/0000-0003-0263-8043 \\ E-mail: joaow95@gmail.com
}

\section{RESUMO:}

O presente artigo procura aproximar os pensamentos de Theodor Adorno e Maurice Blanchot em torno do problema do humanismo. O eixo da conversa entre os filósofos é o que podemos continuar chamando com Marx de "questão judaica". Parte-se da intuição blanchotiana da indestrutibilidade do homem e do papel do judaísmo na revelação de uma relação exorbitante entre os homens em virtude da presença de Outrem, investigando-se em seguida o papel aparentemente contrário do judaísmo na dialética do esclarecimento de Adorno e Horkheimer. Neste percurso, dois pontos se destacam: a crítica à dialética hegeliana, mas também a reabilitação da dialética como antídoto contra a regressão do esclarecimento; e o potencial humanista retido no conceito de mimese, sobretudo na obra adorniana, o qual também possibilita a ressignificação do judaísmo no âmbito da dialética do esclarecimento.

PALAVRAS-CHAVE: Dialética; Mimese; Judaísmo; Humanismo.

\section{FROM NOBODY TO AUTRUI: DIALECTICS AND MIMESIS, JUDAISM AND HUMANISM AFTER BLANCHOT AND ADORNO}

\begin{abstract}
:
This article aims to bring together the thoughts of Theodor Adorno and Maurice Blanchot around the problem of humanism. The "jewish question", as we can still call it along with Marx, is the central issue of this conversation. Starting from Blanchot's intuition regarding the indestructibility of man and the role of judaism in revealing an exorbitant relation between men in the presence of Autrui, the article follows examining the seemingly opposite role of judaism in Adorno's and Horkheimer's dialectic of enlightenment. In this path, two topics stand out: the critique of hegelian dialectics, but also the rehabilitation of dialectics as an antidote to the regression of enlightenment; and the humanistic potencial retained in the concept of mimesis, especially in Adorno's work, concept which also allows the resignification of judaism inside the dialectic of enlightenment.
\end{abstract}

KEYWORDS: Dialectics; Mimesis; Judaism; Humanism.

\footnotetext{
${ }^{1}$ Doutorando(a) em Filosofia na Universidade do Estado do Rio de Janeiro (UERJ), Rio de Janeiro - RJ, Brasil.
}

SANTOS, João Wilson Sobral. De ninguém a outrem: dialética e mimese, judaísmo e humanismo a partir de Blanchot e Adorno. Griot : Revista de Filosofia, Amargosa-BA, v.21 n.3, p.15-34, outubro, 2021. 
O que está vivo é apenas uma variedade daquilo que está morto, e uma variedade bastante rara (NIETZSCHE, 1882, p. 136 (A gaia ciência, $\S 109)$.

"Só os fragmentos enquanto forma da filosofia seriam capazes de entregar às mônadas projetadas de maneira ilusória pelo idealismo o que lhes é devido. Elas seriam representações no particular da totalidade irrepresentável enquanto tal" (ADORNO, 2009, p. 32). Enquanto Blanchot encontra a especificidade do fragmento preferencialmente em Nietzsche, Adorno a encontra recorrendo a uma genealogia que remonta à monadologia leibniziana, certamente via Benjamin. As afinidades eletivas entre Blanchot e Adorno sem dúvida também passam pelo privilégio à forma ensaística de apresentação (darstellung) filosófica. $\mathrm{O}$ ensaio como forma não foi só explicitamente defendido por Adorno, mas magistralmente desenvolvido por Blanchot em $A$ conversa infinita $(1969)^{2}$. Um dos ensaios dessa obra, intitulado $O$ indestrutível, fornece a intuição que impulsiona o presente artigo: "o homem é o indestrutível que pode ser destruído" (BLANCHOT, 2007, p. 80).

Para Blanchot, isso é uma verdade, quiçá $a$ verdade. Pois o referido ensaio, dividido em duas partes, faz um movimento de mediação entre questão particular e questão universal: a própria constituição do Ser judeu (primeira parte) depende de $A$ espécie humana (segunda parte), e vice-versa. No entanto, tudo que não se quer é que essa relação se esgote na mútua negação à maneira de certa dialética tradicionalmente reportada a Hegel, fazendo com que aquela verdade se dogmatize. A argumentação de Blanchot quer fugir disso. Ser judeu tem de ser mais que o Outro do homem, a diferença particular negada pela universalidade humana, porque isso quase colocaria a universalidade e o antissemitismo do mesmo lado. Daí a inquietação básica da primeira parte: ser judeu é só uma condição negativa, mal-estar e infelicidade? Não. O judeu é uma condição positiva; mais ainda, afirmativa. Ele encarna uma verdade acerca da relação dos homens entre si denominada "judaísmo", cujo conteúdo reside na própria experiência existencial que formou o judeu. É uma verdade nômade, errante, habitação simultânea do exílio e do reino, que "finalmente proíbe a tentação da Unidade-Identidade" (BLANCHOT, 2007, p. 72). A verdade do ser judeu, que implica a espécie humana, é ser Outrem (Autrui).

“Quem é outrem?" é a pergunta que inicia a segunda parte do ensaio, mas já trabalhada anteriormente no ensaio $A$ relação do terceiro tipo. Blanchot esquematiza as relações entre os homens em três tipos: a relação mediata (seja baseada no reconhecimento dialético do outro, seja na sua dominação ou instrumentalização), a relação imediata de instantânea fusão e a relação do terceiro tipo, na qual "a presença do outro não nos remeteria nem a nós-mesmos, nem ao Uno" (BLANCHOT, 2001, p. 120), mas à pura interrupção ou estranheza entre um homem e outro, relação exterior/exorbitante, sem igualdade nem horizonte. A separação infinita só pode ser atravessada pela palavra plural, "quando falar não é ver", "mas inaugura uma relação que não seria de sujeito a sujeito nem de sujeito a objeto" (BLANCHOT, 2001, p. 123). Por isso, "quem" é um termo simplesmente descabido. "Outrem é, portanto, o Outro, quando não é sujeito... poderíamos dizer que Outrem não tem ego, mas que essa falta não faz dele um objeto" (BLANCHOT, 2001, p. 124). Para Blanchot, a armadilha da dialética à espreita é que ela sempre acaba engajando os relata numa relação de igualdade, de reciprocidade na contradição, quando só há dupla descontinuidade "ao mesmo tempo infinitamente negativa e infinitamente

\footnotetext{
2 No terceiro tomo desta obra, A ausência de livro, Adorno é diretamente citado a respeito da nova música serial (ars nova), que Blanchot aproxima da obra de arte fragmentária. A questão do humanismo, central no presente artigo, também aparece. A arte é a força que expande o humanismo muitas vezes empedernido na cultura (BLANCHOT, 1969, pp. 93-100).
} 
positiva, de modo que deva ser chamada de neutra, se se compreende que o neutro não anula, não neutraliza esta infinidade com duplo sinal, mas a carrega como um enigma" (BLANCHOT, 2001, p. 125). Assim, a pergunta “quem é outrem?" deveria ser substituída por "O que acontece com a comunidade humana, quando deve responder a esta relação de estranheza entre o homem e o homem que a experiência da linguagem conduz a pressentir...?" (BLANCHOT, 2001, p. 125). A remissão à comunidade faz o mesmo movimento supracitado em direção ao universal e permanece como tarefa, enquanto "o que acontece" geralmente é uma situação de risco: a redução de Outrem a Outro, e assim a possibilidade de sua morte, de sua destruição. "Quem encontra Outrem não pode relacionar-se com ele a não ser pela violência mortal ou pelo dom da palavra em sua acolhida" (BLANCHOT, 2007, p. 77).

Ser judeu é encarnar o risco de ser Outrem, risco de toda uma espécie. Tudo o que se passa no campo de concentração entre judeus e seus algozes é a redução forçada dos homens ao Outro destrutível - mas também redução ao Outro que destrói e que só por um antropomorfismo pode ainda ser chamado homem, pois o homem mesmo já desapareceu (BLANCHOT, 2007, pp. 81-82). Para Blanchot, isso tem a ver com a dialética do senhor e do escravo. Mas aí, a dupla limitação que favorece o poder dominador real ainda não é tudo, ainda não pode tudo diante da relação sem relação com Outrem que emerge ali mesmo onde o Outro é destruído. Essa relação guarda um último direito inalienável ao silêncio, sem dúvida eloquente, enquanto o inquisidor quer fazer falar para poder identificar e matar o Outro que fala. No silêncio há uma afirmação derradeira: a pura necessidade da vida nua, "necessidade vazia e neutra, portanto virtualmente de todos" (BLANCHOT, 2007, p. 84), também chamada de terrível "egoísmo sem ego" (BLANCHOT, 2007, p. 83)3. É nessa necessidade vital que remete a uma "comunidade anônima" onde reside o elemento indestrutível da espécie humana. É preciso que isso ganhe uma estrutura coletiva, torne-se uma reivindicação comum, aspire ao poder. Neste ponto, o ensaio retoma surpreendentemente as categorias de luta dialética e totalidade sem os escrúpulos anteriores (BLANCHOT, op. Cit., pp. 84-85). O saldo parece ser que a precariedade de Outrem tanto possibilita um humanismo renovado baseado na diferença infinita, quanto um niilismo extremo. Não por acaso o ensaio seguinte a $O$ indestrutível envereda pelo niilismo nietzschiano. Mas para Blanchot, é como se o judaísmo fosse um "ticket" (parodiando Adorno e Horkheimer) para aquele humanismo que cultiva a "boa indestrutibilidade" do homem, sua verdade, apesar do risco constante da indestrutibilidade ruim.

\footnotetext{
3 A fórmula "egoísmo sem ego" tem ressonâncias nietzschianas particularmente interessantes para a presente discussão, a despeito da pecha de egocêntrico e narcisista atribuída a Nietzsche. Ciente da polêmica, o próprio filósofo várias vezes tenta se explicar, por exemplo, criticando o ego como ilusão e a distinção altruísmo/egoísmo como contrassenso psicológico (Ecce Homo, Por que escrevo tão bons livros, §5). Em La philosophie de l'esprit libre, Wotling dedica um capítulo à questão, cujo subtítulo é precisamente "L'égö̈sme contre l'ego" e afirma: "Il devient donc nécessaire de penser um égoïsme sans ego, c'est-à-dire de reconnaître avant tout le caractere multiple de la personne, du soi-disant "sujet", et refuser la tendance métaphysique qui pousse toujours à réduire le multiple à de l'unité... Défendre les droits de l'égoïsme s'avère ainsi, chez Nietzsche, viser tout autre chose qu'une medíocre et facile recherche de satisfactions terre à terre. C'est au contraire s'éduquer à la première vertu du philosophe: s'imposer la rigueur d'une discipline pulsionnelle au servisse de l'indépendence" (WOTLING, 2008, pp. 283-284). Apesar de serem observações acuradas, o egoísmo em Nietzsche vai além da crítica à ilusão do ego identitário e da defesa de uma disciplina da autenticidade frente à moral do rebanho; ele pode chegar a um verdadeiro humanismo. No aforismo intitulado " $O$ valor natural do egoísmo", Nietzsche afirma que o indivíduo não é nada por si, "ele é toda linha "ser humano" até ele mesmo" e pode continuar fazendo parte da ascensão dessa linha, ou não (Crepúsculo dos Ídolos, Incursões de um extemporâneo, §33). Outros dois aforismos que apresentam um egoísmo extrovertido e não autocentrado utilizam os símbolos da paternidade (Humano, demasiado humano, §455) e da maternidade (Aurora, §552) no sentido de promover a continuidade da linha humana. Obviamente, esta interpretação não está imune a críticas e mereceria uma discussão à parte.
}

SANTOS, João Wilson Sobral. De ninguém a outrem: dialética e mimese, judaísmo e humanismo a partir de Blanchot e Adorno. Griot : Revista de Filosofia, Amargosa - BA, v.21 n.3, p.15-34, outubro, 2021. 
Por arbitrário que seja ater-se a essas observações, não creio que sua direção falseie a verdade. E essa verdade é que aquele que queira ler o sentido da história dos judeus através do judaísmo deve refletir sobre essa distância que separa o homem do homem quando ele está em presença de Outrem. Os judeus não são diferentes dos outros, como deseja persuadir-nos o racismo, mas aquilo de que dão testemunho é dessa relação com a diferença, cujo rosto humano, como o diz Levinas (o que no rosto é irredutível à visibilidade), traz-nos a revelação e confia-nos a responsabilidade; não estranhos, mas recordando-nos a exigência da estranheza; nem separados por um incompreensível castigo, mas designando como pura separação e pura relação que do homem ao homem excede o poder humano, que no entanto pode tudo. $O$ antissemitismo, nesse sentido, não é de modo algum acidental: figura a repulsão que inspira Outrem, o mal-estar diante do que vem de longe e de alhures, a necessidade de matar o Outro, isto é, de submeter à onipotência da morte aquilo que não se mede em termos de poder (BLANCHOT, 2007, p. 77).

Seguindo essa intuição humanista a partir da questão judaica em Blanchot, o presente artigo se volta para as considerações de Adorno e Horkheimer na Dialética do Esclarecimento, pois aí judaísmo parece ser o nome de um fator histórico crucial que colaborou com o processo de mitificação e regressão do esclarecimento ocidental, responsável pela autodestruição do homem. Não obstante, os autores também preveem uma virada no próprio conceito de judaísmo, rearticulando-o ao humanismo, o que fica patente na sexta tese do ensaio Elementos do antissemitismo: “...que o judeu é um ser humano. Isso representaria a passagem da sociedade antissemita, que impele os judeus e os demais para uma condição patológica, para a sociedade humana" (ADORNO; HORKHEIMER, 2006, p. 164). Assim como em Blanchot, não se trata de negar o particular por meio do universal, e sim de concretizar o universal. Nas três partes deste artigo que se seguem, serão analisados três ensaios da Dialética do Esclarecimento, respectivamente, $O$ conceito de Esclarecimento, Excurso I: Ulisses ou Mito e Esclarecimento e o já citado Elementos do antissemitismo: limites do esclarecimento, ao longo dos quais se pretende ainda evidenciar como a reconciliação entre judaísmo e humanismo é retida no conceito de mimese. Este conceito mereceu uma última recensão levemente mais detalhada devido a sua importância na obra de Adorno, enquanto a Nota sobre a interversão se justificou diante das controvérsias envolvendo o pensamento dialético que surgem não só para Blanchot e Adorno, mas para uma parte significativa da tradição filosófica.

\section{O esclarecimento mitificado e sua superação dialética}

Há uma dialética entre o mito e o esclarecimento. Mas também uma dialética entre a realidade social e a racionalidade, entre a natureza e a dominação da natureza. A crítica dialética "deve preparar um conceito positivo do esclarecimento, que o solte do emaranhado que o prende a uma dominação cega" (ADORNO; HORKHEIMER, 2006, p. 15). Pois o programa do esclarecimento é o desencantamento, a desmitificação do mundo. No entanto, ao se desvencilhar do mito, o esclarecimento tende a perder a verdade do mito e a conservar em si o mito da verdade. $O$ mito da verdade é conservado no esclarecimento na medida em que ele desenvolve seus próprios critérios de causalidade e utilidade com relativa independência da natureza e a partir daí é capaz de dominar a natureza e os homens, segundo uma lógica formal e unitária: daí porque, para Adorno e Horkheimer, o totalitarismo e a sociedade burguesa dominada pela equivalência do capital são insidiosamente aparentados.

SANTOS, João Wilson Sobral. De ninguém a outrem: dialética e mimese, judaísmo e humanismo a partir de Blanchot e Adorno. Griot : Revista de Filosofia, Amargosa - BA, v.21 n.3, p.15-34, outubro, 2021. 
O que se passa nos primórdios do mito? O xamã se assemelha às forças que conjura: se são assustadoras, ele assume um ar assustador; se são suaves, ele fica suave. Há uma solidariedade profunda entre a pessoa e seus pertences ou atributos ou seu nome - como acontece no vodu. $O$ sacrifício, mesmo quando passou a admitir substituições (que apontavam para a indiferenciação), não significava uma repetição automática, mas o "introcável na troca". O contexto mítico ainda preserva um modo de vida anterior ao mito que Adorno e Horkheimer chamam mimético, e que consiste numa rede de múltiplas afinidades e aproximações entre homem e natureza: "como a ciência, a magia visa fins, mas ela os persegue pela mimese, não pelo distanciamento progressivo em relação ao objeto". Mimese significa uma condição de liberdade e abertura para assimilações, descentramentos, influências mútuas, nada a ver com a imitação ou a cópia deliberadas que são da ordem da imitação. O feiticeiro "ainda não se declarou à imagem e semelhança do poder invisível". Quando isso acontece, não há mais a rica substitutividade da mimese, mas a fungibilidade monótona da ratio. "É só enquanto tal imagem e semelhança que o homem alcança a identidade do eu que não pode se perder na identificação com o outro, mas toma definitivamente posse de si como máscara impenetrável" (ADORNO; HORKHEIMER, 2006, p. 22). Note-se que a insistência na fórmula genesíaca, "imagem e semelhança" (Gn 1, 26 - TEB, 1994, p. 25), sugere a forte imbricação entre questão judaica e esclarecimento ocidental, tema específico do ensaio final da Dialética do Esclarecimento.

Mas como o mito se torna esclarecimento? Há uma transição em que ele deixa de ser relato vivo e se autonomiza enquanto ritual, representação, doutrina. Esse já é o momento da imitação do mesmo e da alienação daquilo que doravante é objeto de dominação. Em seguida,o mito é alienado do esclarecimento, e dominado, enquanto antropomorfismo, isto é, o próprio homem se abstrai de si e declara a imagem e semelhança de todas as figuras míticas consigo. Isso significa que, no âmbito do esclarecimento, o homem troca a relação mimética por uma relação instrumental ou de dominação, o que acaba se revelando autoalienação mal-resolvida por intermédio da dominação do outro. "A distância do sujeito com relação ao objeto, que é o pressuposto da abstração, está fundada na distância em relação à coisa, que o senhor conquista através do dominado" (ADORNO; HORKHEIMER, 2006, p. 24). Essa afirmação que ecoa a dialética do senhor e do escravo hegeliana diz o seguinte: a coisa ou o objeto é o próprio homem na medida em que ele se declarou imagem e semelhança do mito conforme o instrumental demasiado humano do esclarecimento, isto é, abstraindo-se, e tem de ser reconquistada, não pelo trabalho na reconstrução desse vínculo, mas pela dominação de quem trabalha - Ulisses, como protótipo do burguês emancipado, gozando do belo canto das sereias às custas da tripulação.

Entretanto, mais do que a possibilidade de uma apreciação artística "neutra" (Ulisses prefigura a elite que comparece aos concertos modernos, imóvel e aplaudindo mecanicamente), o que realmente está em jogo neste episódio é o nostos (ADORNO; HORKHEIMER, 2006, p. 59), o retorno à terra natal. $\mathrm{O}$ canto das sereias é ambíguo porque ele de fato ameaça a coesão do ego que guia este retorno com toda a astúcia e diligência, mas também promete uma outra reconciliação, uma outra morada precisamente com a dissolução do ego inflexível. $O$ tema do nostos permite a Adorno e Horkheimer, simultaneamente, criticar a questão judaica, ou melhor, sionista, muito candente à época (a publicação de Dialética do Esclarecimento e a criação do Estado de Israel são ambas de 1947), e criticar a separação entre arte e conhecimento no interior 
do esclarecimento mitificado: "a arte reclama a dignidade do absoluto" (ADORNO; HORKHEIMER, 2006, p. 29). ${ }^{4}$

Não obstante, o esclarecimento desemboca de novo no mito. Pois, a partir da primeira abstração da imagem, uma cópia do homem (o antropomorfismo que o esclarecimento acusa no mito), tudo se passa como reprodução da dominação real, factual e, ao mesmo tempo, permanência de uma assombrosa, verdadeiramente mítica contradição inexorável na existência que reside no próprio gesto do esclarecimento, a abstração, mas que ele mesmo oculta e mistifica, nega.

Na pregnância da imagem mítica, bem como na clareza da fórmula científica, a eternidade do factual se vê confirmada e a mera existência expressa como o sentido que ela obstrui... O preço da dominação não é meramente a alienação dos homens com relação aos objetos dominados; com a coisificação do espírito, as próprias relações dos homens foram enfeitiçadas, inclusive as relações de cada indivíduo consigo mesmo. (ADORNO; HORKHEIMER, 2006, pp. 34-35)

Se a declaração da imagem e da semelhança de deus e o posterior tabu de fazer ídolos têm uma mesma proveniência é porque decorrem do mesmo gesto fundamental que desencanta reencantando: "o mundo desencantado do judaísmo reconcilia a magia através de sua negação na ideia de Deus" (ADORNO; HORKHEIMER, 2006, p. 32). O antídoto contra essa negação que Adorno e Horkheimer consideram abstrata é a negação determinada de Hegel:

O direito da imagem é salvo na execução fiel de sua proibição. Semelhante execução, "negação determinada", não está imunizada pela soberania do conceito abstrato contra a intuição sedutora... A negação determinada rejeita as representações imperfeitas do absoluto, os ídolos, mas não como o rigorismo, opondo-lhes a Ideia que elas não podem satisfazer. A dialética revela, ao contrário, toda imagem como uma forma de escrita. Ela ensina a ler em seus traços a confissão de sua falsidade, confissão essa que a priva de seu poder e o transfere para a verdade. Desse modo, a linguagem torna-se mais que um simples sistema de signos. Com o conceito de negação determinada, Hegel destacou um elemento que distingue o esclarecimento da desagregação positivista à qual ele o atribui. É verdade, porém, que ele acabou por fazer um absoluto do resultado sabido do processo total da negação: a totalidade no sistema e na história, e que, ao fazer isso, infringiu a proibição e sucumbiu ele próprio à mitologia. (ADORNO; HORKHEIMER, 2006, p.32)

Esta passagem é importante porque a saída da dialética pervertida do esclarecimento mitológico proposta no texto $O$ conceito de esclarecimento é também hegeliana (mantidas as críticas acima), na medida em que o esclarecimento como conceito vivo depende da operação do conceito de negação determinada. $O$ esclarecimento como conceito, neste preciso sentido, é vivo, pois movimentado pela dialética das contradições - uma dialética que não significa uma infinita interversão entre os opostos dentro do idêntico ${ }^{5}$, mas uma abertura para o não-idêntico, ou conforme chamará Adorno, dialética negativa. Essa dialética já poderia ser entrevista no modo de vida mimético:

\footnotetext{
${ }_{4}^{4}$ Assim, demonstra-se que a arte não fica inteiramente à mercê do esclarecimento dominador, mesmo que Adorno e Horkheimer de fato não tenham privilegiado a dimensão narrativa da epopeia que faz de Ulisses um herdeiro das sereias, como prefere Sussekind, com base em Gagnebin (2013, pp. 177-186).

5 Cf. adiante a "Nota sobre a interversão".
}

SANTOS, João Wilson Sobral. De ninguém a outrem: dialética e mimese, judaísmo e humanismo a partir de Blanchot e Adorno. Griot : Revista de Filosofia, Amargosa - BA, v.21 n.3, p.15-34, outubro, 2021. 
Quando uma árvore é considerada não mais simplesmente como árvore, mas como testemunho de uma outra coisa, como sede do mana, a linguagem exprime a contradição de que uma coisa seria ao mesmo tempo ela mesma e outra coisa diferente dela, idêntica e não-idêntica... $\mathrm{O}$ conceito, que se costuma definir como a unidade característica do que nele está subsumido, já era desde o início produto do pensamento dialético, no qual cada coisa só é o que ela é tornando-se aquilo que ela não é. (ADORNO; HORKHEIMER, 2006, p. 26)

Segundo Adorno e Horkheimer, o esclarecimento reificado, isto é, aquele em que o instrumental racional é convertido em instância suprema e dominadora do próprio pensamento e da realidade, acaba reeditando uma necessidade fatal contra a qual o próprio esclarecimento tinha se insurgido, interversão descrita como: "a maldição do progresso irrefreável é a irrefreável regressão" (ADORNO; HORKHEIMER, 2006, p. 41). Neste ponto, ou o esclarecimento perpetua uma negação abstrata e supersticiosa que o cega diante da submissão a si mesmo, ou percebe a negação determinada que ele próprio é, segundo um processo de reconhecimento (reconciliação) do seu enredamento com uma natureza ela mesma contraditória, mas que estava como que esquecida de si e presa na sua própria compulsão racional. $O$ trecho seguinte dá conta da segunda possibilidade e são notórios os termos hegelianos - como espírito, conceito - nos quais Adorno e Horkheimer pensam essa reconciliação, esse retorno à terra natal:

A condenação da superstição significa sempre, ao mesmo tempo, o progresso da dominação e o seu desnudamento. O esclarecimento é mais que esclarecimento: natureza que se torna perceptível em sua alienação. No autoconhecimento do espírito como natureza em desunião consigo mesma, a natureza se chama a si própria como antigamente, mas não mais imediatamente com seu nome presumido, que significa onipotência, isto é, como "mana", mas como algo de cego, mutilado. A dominação da natureza, sem o que o espírito não existe, consiste em sucumbir à natureza. Graças à resignação com que se confessa como dominação e se retrata na natureza, o espírito perde a pretensão senhorial que justamente o escraviza à natureza... a concretização desta perspectiva depende do conceito. Pois ele é não somente, enquanto ciência, um instrumento que serve para distanciar os homens da natureza, mas é também, enquanto tomada de consciência do próprio pensamento que, sob a forma da ciência, permanece preso à evolução cega da economia, um instrumento que permite medir a distância perpetuadora da injustiça. Graças a essa consciência da natureza no sujeito, que encerra a verdade ignorada de toda cultura, o esclarecimento se opõe à dominação em geral. (ADORNO; HORKHEIMER, 2006, p. 44).

\section{Ulisses: burguês e judeu}

Apesar de admitirem, logo no início do primeiro excurso, que Nietzsche, desde Hegel, era um dos poucos a conhecer a dialética do esclarecimento, a relação contraditória do esclarecimento com a dominação, Adorno e Horkheimer também não tardam a apontar a relação contraditória do próprio Nietzsche com o esclarecimento: "ele enxergava no esclarecimento tanto o movimento universal do espírito soberano, do qual se sentia o realizador último, quanto a potência hostil à vida, niilista" (ADORNO; HORKHEIMER, 2006, p. 48). Essa contradição que, não obstante, permanece fértil em Nietzsche, foi arrematada pelo fascismo com a exaltação ideológica só do segundo aspecto.

A tese do Excurso I é que a epopeia homérica se opõe ao mito na medida em que as aventuras de Ulisses são todas uma grande fuga do sujeito (já prototipicamente moderno e

SANTOS, João Wilson Sobral. De ninguém a outrem: dialética e mimese, judaísmo e humanismo a partir de Blanchot e Adorno. Griot : Revista de Filosofia, Amargosa - BA, v.21 n.3, p.15-34, outubro, 2021. 
burguês) diante das potências míticas da dissolução do eu: "a oposição do ego sobrevivente às múltiplas peripécias do destino exprime a oposição do esclarecimento ao mito" (ADORNO; HORKHEIMER, 2006, p. 49). Segundo os autores, o recurso do eu para sobreviver, a astúcia, consiste em "perder-se para se conservar", levando ao tema do sacrifício e da renúncia. A astúcia de Ulisses advém da astúcia contida no sacrifício aos deuses, ele atua como vítima e sacerdote, crente e incrédulo: “o próprio sacrifício já aparece como o esquema mágico da troca racional, uma cerimônia organizada pelos homens com o fim de dominar os deuses, que são derrubados exatamente pelo sistema de veneração de que são objetos" (ADORNO; HORKHEIMER, 2006, p. 51). A contribuição de Ulisses é elevar o logro do deus à consciência de si, forjar o ego a partir do seu sacrifício, daí o ego nunca ter conseguido esconder totalmente o embuste pelo qual obtém para si a dominação. O autossacrifício que forja o eu é a maneira etnológica de Adorno e Horkheimer se referirem mais uma vez àquele instrumento do esclarecimento, a abstração, a negação da natureza no homem que funda as relações de dominação ao mesmo tempo em que proscreve as relações miméticas. A citação é longa, mas vale por sua clareza:

\begin{abstract}
Na história das classes, a hostilidade do eu ao sacrifício incluía um sacrifício do eu, porque seu preço era a negação da natureza no homem, em vista da dominação sobre a natureza extra-humana e sobre os outros homens. Exatamente essa negação, núcleo de toda racionalidade civilizatória, é a célula da proliferação da irracionalidade mítica. Com a negação da natureza no homem, não apenas o telos da dominação externa da natureza, mas também o telos da própria vida se torna confuso e opaco. No instante em que o homem elide a consciência de si mesmo como natureza, todos os fins para os quais ele se mantém vivo - o progresso social, o aumento de suas forças materiais e espirituais, até mesmo a própria consciência - tornam-se nulos, e a entronização do meio como fim, que assume no capitalismo tardio o caráter de um manifesto desvario, já é perceptível na proto-história da subjetividade. O domínio do homem sobre si mesmo, em que se funda o seu ser, é sempre a destruição virtual do sujeito a serviço do qual ele ocorre; pois a substância dominada, oprimida e dissolvida pela autoconservação, nada mais é senão o ser vivo, cujas funções configuram, elas tão somente, as atividades da autoconservação, por conseguinte exatamente aquilo que na verdade devia ser conservado. A antirrazão do capitalismo totalitário, cuja técnica de satisfazer necessidades, em sua forma objetualizada, determinada pela dominação, torna impossível a satisfação de necessidades e impele ao extermínio dos homens - esta antirrazão está desenvolvida de maneira prototípica no herói que se furta ao sacrifício sacrificando-se. (ADORNO; HORKHEIMER, 2006, pp. 53-54)
\end{abstract}

O sentido desse trecho é muito contundente, pois Adorno e Horkheimer chamam a atenção para a face não só genocida, mas suicida do esclarecimento. A abstração da natureza de si, modo que possibilita a dominação, decreta ao mesmo tempo a própria morte. Em outras palavras, essa operação é suicida porque separa espírito e força, espírito e energia vital. "Mas isso deriva do fato de que, na sociedade de classes, todo poderio está ligado à consciência incômoda da própria impotência diante da natureza e de seus herdeiros sociais, a maioria. Só a adaptação conscientemente controlada à natureza coloca-a sob o poder dos fisicamente mais fracos" (ADORNO; HORKHEIMER, 2006, p. 55). Esta observação é tipicamente nietzschiana: a vitória dos fracos, da moral escrava, obtida por uma inversão de valores que nada mais é senão vontade de nada, querer perecer. Para Adorno e Horkheimer, essa inversão é como um fingir-se de morto. Abstraído, o homem recalca a mimese com a ratio, mas já se viu de que maneira: ele declara os poderes míticos à imagem e semelhança d'ele mesmo, sendo que ele mesmo já está condenado, sacrificado e morto. A cópia da mimese, imitação a serviço da dominação, é imitação

SANTOS, João Wilson Sobral. De ninguém a outrem: dialética e mimese, judaísmo e humanismo a partir de Blanchot e Adorno. Griot : Revista de Filosofia, Amargosa - BA, v.21 n.3, p.15-34, outubro, 2021. 
do morto. Assim, "até o homem se transforma em um antropomorfismo para o homem" (ADORNO; HORKHEIMER, 2006, p. 55), pois já não se trata do homem, mas de uma coisa morta que retém sua imagem e que se tornou modelo.

Por tudo isso, a astúcia do esclarecimento é também estado de exceção. É submetendo-se aparentemente à lei da sua natureza que o homem se excetua dela; sacrificando-se a ela, dominaa. A consciência da lei funciona como justificação ideológica para o domínio. O esclarecimento regride ao mito na exata medida em que simplesmente inverte o pólo mítico da dominação. Se, no entanto, essa inversão é uma astúcia ideológica, ela não produz verdadeiramente exceção ou liberação, mas sim o aprofundamento da servidão. $O$ esclarecimento se revela puramente formal e a essência do formalismo é a capacidade de vigência mesmo quando contrariada por um conteúdo prático. $\mathrm{O}$ estado de exceção é aquele em que a lei oficial continua vigendo enquanto é violada na prática. Do mesmo modo, o esclarecimento aparenta uma razão livre enquanto potencializa a servidão real.

Há dois exemplos marcantes da exceção na Odisséia. O primeiro é o próprio episódio das sereias: Ulisses é submetido ao canto das sereias, porém alienado, amarrado pela tripulação "ele arranjou um modo de, entregando-se, não ficar entregue a elas" (ADORNO; HORKHEIMER, 2006, p. 57). O segundo é o encontro de Ulisses com o ciclope Polifemo. Ulisses "se finge de morto" na medida em que se identifica como "ninguém" (conforme um trocadilho grego entre Odysseus e Oudeis), isto é, ele obedece a lei que obriga a autoidentificação negando-a, oferecendo-a um conteúdo vazio que a frauda.

Na verdade, o sujeito Ulisses renega a própria identidade que o transforma em sujeito e preserva a vida por uma imitação mimética do amorfo... Mas sua autoafirmação é, como na epopeia inteira, como em toda civilização, uma autodenegação. Desse modo o eu cai precisamente no círculo compulsivo da necessidade natural ao qual tentava escapar pela assimilação. Quem, para se salvar, se denomina Ninguém e manipula os processos de assimilação ao estado natural como um meio de dominar a natureza sucumbe à hybris. (ADORNO; HORKHEIMER, 2006, p. 63)

A astúcia do esclarecimento, a maneira burguesa de se autoconservar é mais uma vez caracterizada como abstração ou autoafirmação/autodenegação. Ela opera mediante a manipulação dos processos de assimilação, manipulação da mimese, e por isso só pode ser mera cópia ou imitação do amorfo, do morto. Por isso, finalmente, o esclarecimento regride ao mito ao recair na superstição, conservando contra si mesmo um poder superior que continua a submetêlo: o esclarecimento recai no formalismo fetichista, no estado de exceção.

Quando os autores estendem o expediente de Ulisses para "toda civilização" é inevitável recordar a crítica ao formalismo da própria subjetividade moderna, tal como elaborada por Marx em $A$ questão judaica. Os direitos do homem $e$ do cidadão só aparentemente estão vinculados. A figura do cidadão representa uma emancipação política, meramente formal, que quase sempre não corresponde à emancipação humana real, de modo que o homem se declara cidadão (ou ninguém) para continuar sendo "homem separado do homem e da comunidade" (MARX, 2010, p. 48) ${ }^{6}$. Assim, “a vida política se declara como um simples meio, cujo fim é a

\footnotetext{
${ }^{6}$ Blanchot, em nota, segue a tradição desta crítica marxiana quando afirma que a questão do ser-judeu e a do Estado de Israel, apesar de influenciarem uma à outra, não se identificam: "se essa tarefa ela própria - a que passa pela edificação de uma morada e, finalmente, de um Estado - responde parcialmente à questão da salvaguarda dos judeus, não pode constituir uma resposta à questão que coloca o ser-judeu e que é uma questão universal" (BLANCHOT, 1969, p. 79). A verdade nômade não se reduz à razão de Estado.
}

SANTOS, João Wilson Sobral. De ninguém a outrem: dialética e mimese, judaísmo e humanismo a partir de Blanchot e Adorno. Griot : Revista de Filosofia, Amargosa - BA, v.21 n.3, p.15-34, outubro, 2021. 
vida da sociedade burguesa" (MARX, 2010, p. 51). De acordo com o destaque do próprio Marx, significa dizer que o homem separado do homem, da comunidade e da natureza, que se abstraiu e por isso se esclareceu, faz da própria abstração o meio através do qual é possível viver alienado. O próprio homem tem então de se converter em meio. Isso é importante para se compreender o momento mais polêmico do primeiro Excurso da Dialética do Esclarecimento, a associação entre Ulisses e o judeu.

A dialética da interversão entre mito e esclarecimento segue, portanto, um roteiro vertiginoso, que Adorno e Horkheimer preferem denominar maníaco ou compulsivo. $\mathrm{O}$ sujeito esclarecido que, amedrontado, não hesita em renunciar a si mesmo para dominar, não pode suportar o anonimato por muito tempo, pois isso o precipitaria num abismo, e tem de se afirmar novamente na dominação real, de maneira mais cruel e cínica, para depois de novo desaparecer, e assim sucessivamente. Após se safar como Ninguém, Ulisses precisa judiar o ciclope e revela seu nome sadisticamente. Adorno e Horkheimer chamam a isso "dialética da eloquência", elemento característico do esclarecimento: discurso compulsivo que tenta aparentar superioridade quando, na verdade, advém de um profundo medo. É então que surge uma desconcertante comparação:

\begin{abstract}
Oudeis, que se dá compulsivamente a conhecer como Ulisses, já apresenta os traços característicos do judeu que, mesmo na angústia da morte, se gaba da superioridade que dela resulta; e a vingança contra o mediador não aparece só ao fím da sociedade burguesa, mas já está em seu começo como a utopia negativa à qual toda forma de violência sempre tende. (ADORNO; HORKHEIMER, 2006, p. 64)
\end{abstract}

Primeiramente, o judaísmo do esclarecimento que permeia a comparação não pode surpreender, visto que o ensaio inicial de Dialética do Esclarecimento apresentou em termos judaicos, por assim dizer, tanto a falsa imitação dos poderes míticos que decorre do mecanismo da abstração ("fazer-se imagem e semelhança"), quanto a lei-mor do esclarecimento coincidente com o segundo mandamento, o princípio iconoclasta. Mesmo assim, invocar essa genealogia distante é muito mais tranquilo do que invocar o judeu à beira do extermínio. No entanto, para compreender a comparação entre Ulisses e o judeu ${ }^{7}$ é preciso voltar ao tema central do autosacrifício e àquela consequência derradeira: o telos da dominação se anula e o esclarecimento passa a agredir a própria vida, indo do genocídio ao suicídio. Adorno e Horkheimer, intelectuais de ascendência judaica, são honestos o bastante para reconhecerem que os judeus enquanto raça - um delírio; ou mesmo enquanto povo autodeterminado (política e/ou religiosamente) - não precedem o ser humano, este sim a questão em jogo. Além disso, são duros o bastante para apontarem um autoengano fatal dos judeus: eles padecem do próprio judaísmo; não particularmente da religião, mas daqueles elementos judaicos que se aliaram ao esclarecimento, tornaram-se hegemônicos e finalmente passaram a trucidar o próprio judeu, além de marginaliza-lo secularmente. Embora aterradora, a Shoáh não é "privilégio" dos judeus e acontece onde quer que o esclarecimento se torne mito. No trecho em comento, o judeu que se regozija morrendo é o ícone perturbador, mas absolutamente necessário para se fazer a crítica radical da sociedade burguesa e esclarecida incubadora do fascismo. O judeu que se regozija morrendo revela a face suicidária da sociedade como um todo, o que o Telegrama 71 de Hitler

\footnotetext{
${ }^{7}$ Cf. também sobre este ponto específico o artigo de James I. Porter, Odysseus and the Wandering Jew: The Dialectic of Jewish Enlightenment in Adorno and Horkheimer (2010, pp. 200-213).
}

SANTOS, João Wilson Sobral. De ninguém a outrem: dialética e mimese, judaísmo e humanismo a partir de Blanchot e Adorno. Griot : Revista de Filosofia, Amargosa - BA, v.21 n.3, p.15-34, outubro, 2021. 
("Si la guerre est perdue, que la nation périsse") $)^{8}$ só veio confirmar. Por isso, "ninguém" se adapta tanto à ficção jurídico-política - o plano do cidadão, quanto ao mais nu e cru extermínio - o plano do homem. E Ulisses, o judeu, sabe disso. Ele mesmo se converteu em meio para sua própria aniquilação ${ }^{9}$. O judaísmo, neste preciso sentido, representa o racismo, a violência que a sociedade esclarecida sempre acaba por impor a si mesma, na medida em que emerge como "utopia negativa".

\section{Judaísmo, ticket para um novo humanismo}

Elementos do antissemitismo, último ensaio de Dialética do Esclarecimento, dividido em sete teses, pode ser lido imediatamente a partir daí: “Os judeus são hoje o grupo que, tanto prática quanto teoricamente, atraem sobre si a vontade de destruição que uma falsa ordem social gerou dentro de si mesma. Assim, eles são de fato o povo eleito" (ADORNO; HORKHEIMER, 2006, p. 139). É porque o judeu jamais está verdadeiramente fora da ordem social que, no sentido da ácida ironia, sua eleição ou exceção (ex-capere: capturar fora) é produto dessa mesma ordem, converge para uma mesma projeção doente: "os racistas exprimem sua própria essência na imagem que projetam dos judeus" (ADORNO; HORKHEIMER, 2006, p. 139). Ora, a essência dessa "falsa ordem social" é a universalização ideal da abstração ou da segregação reais - da propriedade privada, diria Marx. Por isso, o fascismo não está longe do liberalismo: "A raça, hoje, é a autoafirmação do indivíduo burguês integrado à coletividade bárbara" (ADORNO; HORKHEIMER, 2006, p. 140).

$\mathrm{Na}$ tese II, os autores avaliam a sustentabilidade da explicação de que o antissemitismo seria como uma "válvula de escape". Ele seria a fúria correspondente a uma massa infeliz, quando ela pressente que os direitos humanos universais são um engodo e se depara com algumas concessões liberais locais de "felicidade sem poder". Assim, as vítimas são intercambiáveis segundo a conjuntura (vagabundos, judeus, cristãos, ciganos, homossexuais, etc.) e podem se tornar os algozes: "perseguidores e vítimas pertencem ao mesmo círculo funesto" (ADORNO; HORKHEIMER, 2006, p. 141). No caso do judeu, as imagens do banqueiro e do intelectual são os sinais que canalizam o ódio generalizado: "o dinheiro e o espírito, expoentes da circulação, são o sonho renegado daqueles que a dominação mutilou e de que ela se serve para sua própria perpetuação" (ADORNO; HORKHEIMER, 2006, p. 143).

Com a consolidação da burguesia - continua a tese III -, a dominação foi disfarçada pela produção, pela "ideologia que encobria a essência do contrato de trabalho e a natureza rapinante do sistema econômico em geral" (ADORNO; HORKHEIMER, 2006, p. 144). A massa trabalhadora expropriada na fonte só sente a injustiça quando mede seu poder aquisitivo no mercado. E no mercado, "o comerciante é o oficial de justiça para o sistema inteiro e atrai para si o ódio voltado aos outros. A responsabilidade do setor da circulação pela exploração é uma aparência socialmente necessária" (ADORNO; HORKHEIMER, 2006, p. 144). Adorno e Horkheimer derivam boa parte do antissemitismo, portanto, do tempo demasiado que os judeus ocuparam o setor de circulação, não por vocação, mas por destino (ADORNO;

\footnotetext{
${ }^{8}$ Em Mil Platôs, no capítulo "Micropolítica e segmentaridade", Deleuze e Guattari comentam este telegrama a partir da noção de Paul Virilio de estado suicidário. Cf. DELEUZE; GUATTARI, 1980, pp. 281-283.

9 Cf. "a vingança contra o mediador...". A palavra Mittelsmann, em alemão, middleman, em inglês, recebeu duas traduções diferentes na edição brasileira, mediador e intermediário (ADORNO; HORKHEIMER, 1947, p. 64; 169). Trata-se do estigma do intermediário comercial que se fixou no judeu e lhe atraiu o ódio. Se o Capital consome trabalho morto, a morte se efetiva no momento da circulação, no meio de troca; a lei da queda da taxa de lucro revela sua lógica suicida, a vingança contra si.
}

SANTOS, João Wilson Sobral. De ninguém a outrem: dialética e mimese, judaísmo e humanismo a partir de Blanchot e Adorno. Griot : Revista de Filosofia, Amargosa - BA, v.21 n.3, p.15-34, outubro, 2021. 
HORKHEIMER, 2006, p. 145). Por mais que eventualmente tenham prosperado, quase sempre isso não mudou seu desenraizamento e muito frequentemente se deu pela via da assimilação, do batizado cristão. Segundo os autores, além de, no máximo, serem tolerados na sociedade, sempre dependentes da tutela e da aliança com o poder do momento ${ }^{10}$, os judeus foram usados como emissários do capitalismo, atraíram sobre si a rejeição a tal colonização e no final ainda foram descartados.

\begin{abstract}
Os judeus foram os colonizadores do progresso. Desde a época em que ajudaram, como comerciantes, a difundir a civilização romana entre os gentios europeus, eles sempre foram, em consonância com sua religião patriarcal, os representantes de condições citadinas, burguesas e, por fim, industriais. Eles introduziram formas de vida capitalistas nos diversos países e atraíram sobre si o ódio dos que tinham de sofrer sob elas. Por causa do progresso econômico, que é hoje sua perda, os judeus foram sempre um espinho na carne dos artesãos e camponeses, que o capitalismo desclassificara. Agora, experimentam em sua própria carne o caráter exclusivo e particular do capitalismo. (ADORNO; HORKHEIMER, 2006, p. 145)
\end{abstract}

Por fim, ao final da tese III, os autores afirmam que o antissemitismo é ódio de si mesmo dos aproveitadores dos judeus, "má consciência do parasita" (ADORNO; HORKHEIMER, 2006, p. 145), o que remonta às considerações depreendidas do primeiro excurso.

A tese IV trata das razões religiosas do antissemitismo. Apesar do discurso da raça, a hostilidade religiosa persiste, ainda que como esclarecimento reificado. É ainda uma fé fundamentalista aquilo que dirige o racismo. Assim como Freud tinha feito em Moisés e o monoteísmo, os autores comparam judaísmo e cristianismo. Enquanto o judaísmo era uma fé praticamente indiferenciada da vida nacional, da preocupação com a autoconservação do seu povo, o cristianismo, ao absolutizar o finito (operação sintetizada em Cristo), acabou com a necessidade de autoconservação e se tornou um supranaturalismo espiritualizado, uma "ligação intelectual com o intelectualmente suspeito", o que lembra a famosa lição de Jesus sobre o pagamento dos impostos, dar a Cesar o que é de Cesar, a Deus o que é de Deus (Mt 22, 21 - TEB, 1994, p. 1902). Assim, a religião (o ritual da fé) tende a se tornar o substituto da religião, seja para o consolo cotidiano do fiel mais inofensivo, seja para a purificação racial desejada pelo mais fanático. Por isso, ao contrário de Freud ${ }^{11}$, Adorno e Horkheimer afirmam que o cristianismo é um retrocesso em relação ao judaísmo, o qual ainda manteria uma resistência ao mal sem racionalizá-lo e a ideia de uma beatitude imerecida (ADORNO; HORKHEIMER, 2006, p. 148).

"Tudo o que não se ajustou inteiramente ou que fira os interditos em que se sedimentou o progresso secular tem um efeito irritante e provoca uma repugnância compulsiva" (ADORNO; HORKHEIMER, 2006, p. 149). Na tese V, examina-se o ódio à idiossincrasia, à diferença, e, muito ao estilo freudiano, apela-se a uma "proto-história biológica" segundo a qual a socialização se deve a fixação de reações às ameaças da natureza: "essas reações de contração no homem são esquemas arcaicos de autoconservação" (ADORNO; HORKHEIMER, 2006, p. 149). Quem diz contração, diz repressão. A história dessa repressão que possibilita a formação social segue as fases da mimese, do mito e do esclarecimento: "Inicialmente, em sua fase mágica, a civilização havia substituído a adaptação orgânica ao outro, isto é, o comportamento

\footnotetext{
10 "o direito universal garantido pelo Estado era o penhor de sua segurança; a lei de exceção, seu espantalho" (ADORNO; HORKHEIMER, 1947, p. 145).

11 Em comparação ao judaísmo, Freud afirma que "no tocante ao retorno do reprimido, o cristianismo foi um avanço..." (FREUD, 1939, p. 125).
}

SANTOS, João Wilson Sobral. De ninguém a outrem: dialética e mimese, judaísmo e humanismo a partir de Blanchot e Adorno. Griot : Revista de Filosofia, Amargosa - BA, v.21 n.3, p.15-34, outubro, 2021. 
propriamente mimético, pela manipulação organizada da mimese e, por fim, na fase histórica, pela práxis racional, isto é, pelo trabalho" (ADORNO; HORKHEIMER, 2006, p. 149). O movimento de contração ou repressão já é um movimento de autoconstituição defensiva do ego em detrimento do abandono à diferença e da dissolução miméticos. Trata-se novamente do recurso à abstração. A abstração separa o homem da natureza, que ele sentia como domínio ameaçador da mimese, da perda de si, e permite então que ele imite essa dominação ao contrário, desde que a natureza agora se perca na imagem e semelhança do homem. Toda a discussão em torno do Excurso I é útil aqui. Pois essa operação dificilmente esconde sua astúcia e sua impotência, o fato de que se baseia num autosacrifício, numa autoalienação. $O$ esclarecimento se converte no meio da sua própria servidão e, na prática, a própria sociedade esclarecida tem de pagar a conta. Isso se dá então como mimese da mimese, a imitação daquela mimese (isto é, a inversão da dominação) com a finalidade da sua destruição, que nada mais é do que o expurgo contínuo da própria vida naquilo que ainda insiste nela como natureza. Como nada deixou efetivamente de ser natureza, o esclarecimento precisa atribuir a idiossincracia, a diferença, e para isso qualquer parte vulnerável da sociedade serve (tese II). Ao localizar essa idiossincrasia, o fascismo franqueia o acesso à mimese, mas de modo controlado e visando sua destruição: é o antissemita que instintivamente é levado a imitar o judeu. Isso só pode novamente indicar aquela tendência suicida, autodestrutiva, o ódio a si mesmo (tese III).

Assim como tinha sido sugerido mais claramente no Excurso I, na associação entre Ulisses e o judeu, a tese $\mathrm{V}$ termina associando mais uma vez o judaísmo ao processo histórico do esclarecimento através do patriarcado, do monoteísmo, da conservação da pura exigência ritual em detrimento do poder mágico, da proibição de imagens na religião. Reside paradigmaticamente no judeu, enfim, como "primeiros burgueses", o rompimento com a íntima ligação mimética e natural. Isso não justifica que a idiossincrasia antissemita repouse nos judeus, mas, se o esclarecimento regressivo é produto da civilização judaico-cristã, nada mais "oportuno" que o extermínio dos próprios judeus para demonstrar como essa civilização é nociva contra si mesma.

A tese VI é praticamente um ensaio à parte sobre os elementos psicanalíticos do antissemitismo. Enquanto mimese da mimese, o antissemitismo opera pela detecção da idiossincrasia no outro, pela falsa projeção no outro dos impulsos que não admite em si, criando uma realidade paralela, paranoica. ${ }^{12}$

Há vários modos deficientes de projeção, mas só uma oposição refletida ou a mediação entre o interior e o exterior é uma projeção autêntica: "só a mediação, pela qual o dado sensorial vazio leva o pensamento a toda a produtividade de que é capaz e pela qual, por outro lado, o pensamento se abandona sem reservas à impressão que o sobrepuja, supera a mórbida solidão em que está presa a natureza inteira" (ADORNO; HORKHEIMER, 2006, p. 156). A projeção fascista não experimenta essa reflexão e degenera em mero meio de dominação, arma cega contra os homens e a natureza; seu ego correspondente é inchado e atrofiado ao mesmo tempo, sofre de megalomania e mania de perseguição: “na medida em que o paranoico só percebe o

\footnotetext{
12 Não se discutirá aqui em pormenores como os autores endossam inteiramente a descrição freudiana da paranoia como defesa contra um impulso homossexual (ADORNO; HORKHEIMER, 1947, p. 158), tal como consta na análise do caso Schreber (1911). Apoiado em Martin Jay, Rodrigo Duarte oferece uma crítica sucinta desse expediente em Mímesis e racionalidade (1993, pp. 81-82). Além disso, afastadas as hipóteses de mera patologização ou até mesmo de homofobia, cabe assinalar que a paranoia indica, em última instância, uma fixação narcísica, isto é, fixação na etapa narcísica de desenvolvimento do indivíduo em decorrência da ameaça sentida ante os processos de identificação com o outro. No Seminário II, Lacan compreende a psicose paranoica como integrante do processo de subjetivação habitual na modernidade, o que o aproxima do pensamento frankfurtiano, conforme observa Safatle (2005, p. 35).
}

SANTOS, João Wilson Sobral. De ninguém a outrem: dialética e mimese, judaísmo e humanismo a partir de Blanchot e Adorno. Griot : Revista de Filosofia, Amargosa - BA, v.21 n.3, p.15-34, outubro, 2021. 
mundo exterior da maneira como ele corresponde a seus fins cegos, ele só consegue repetir o seu eu alienado numa mania abstrata" (ADORNO; HORKHEIMER, 2006, p. 157). É isso também que será caracterizado como semicultura, uma projeção de desenvolvimento paralisado, incapaz da reflexão. ${ }^{13}$

O que a penúltima tese procura mostrar é como a paranoia está sempre à espreita do conhecimento. $O$ processo cognitivo dito normal também sofre de sua ingenuidade violenta e irrefletida, e pode se tornar "pensamento objetivador" ou juízo intransigente. A verdade depende inevitavelmente de uma dose de imaginação entre o sujeito e o objeto, mas é aí que a paranoia pode se insinuar. "O pensamento objetivador contém a arbitrariedade do fim subjetivo que é estranho à coisa" (ADORNO; HORKHEIMER, 2006, p. 159) e não vê problema em violenta-la; todo juízo assertivo tem uma brutalidade inerente. Ao invés disso, o verdadeiro pensamento consegue transitar naquele espaço distorcido da imaginação fazendo progressivas correções, mobilizando a negatividade ou a negação determinada (cf. $O$ conceito de esclarecimento), a reflexão. "Ao invés de elaborar intelectualmente o fracasso da pretensão absoluta e assim continuar a determinar seu juízo, o paranoico se aferra à pretensão que levou seu juízo ao fracasso" (ADORNO; HOR KHEIMER, 2006, p. 160).

Para Adorno e Horkheimer, a falsa projeção é um mecanismo inerente ao esclarecimento mítico ou paranoico, ele não sossega enquanto tiver o que perseguir, e o judeu é o preferido por causa de uma série de traços miméticos transformados em traços idiossincráticos, pouco importando se são traços já superados ou totalmente arbitrários: "os traços da felicidade sem poder, da remuneração sem trabalho, da pátria sem fronteira, da religião sem mito". (ADORNO; HORKHEIMER, 2006, p. 164).

O trecho final da tese VI merece ser citado. Identifica-se no próprio judaísmo, paradoxalmente, o conceito capaz de superar o ódio da dominação, a reconciliação, e sua virtude verdadeiramente teologal, a espera. A questão judaica é nitidamente traduzida em termos de questão humana, tanto que o próprio judeu é chamado a vencer o esclarecimento dominador dentro de si. Antes disso, porém, a humanidade toda ainda pode ser considerada raça e não espécie. O que não significa que a humanização se tornaria especismo (outra forma de racialização), haja vista o final do trecho. ${ }^{14}$

O ódio é o negativo da reconciliação. A reconciliação é o conceito supremo do judaísmo, e todo o seu sentido consiste na espera, é da incapacidade de esperar que surge a forma de reação paranoica. Os antissemitas estão em vias de realizar com as próprias forças seu negativo absoluto, eles estão transformando o mundo no inferno que sempre viram nele. Uma reviravolta vai depender da capacidade dos dominados, em face da loucura absoluta, de se tornarem senhores de si mesmos e de por termo a ela. Só com a liberação do pensamento relativamente à dominação e com a eliminação da violência seria possível realizar a ideia que até agora permaneceu uma inverdade, a saber, que o judeu é um ser humano. Isso representaria a passagem da sociedade antissemita, que impele os judeus e os demais para uma condição patológica, para a sociedade humana. Essa passagem realizaria ao mesmo tempo, a mentira fascista, mas como sua contradição: a questão judia se relevaria, de fato, como o movimento decisivo da história. Superando a doença do espírito, que grassa no terreno da autoafirmação imune à reflexão, a humanidade deixaria de ser a contrarraça universal para se tornar a espécie que, embora

\footnotetext{
13 Adorno desenvolve a "teoria da semicultura" em um texto homônimo de 1959.

${ }^{14}$ Rodrigo Duarte, no trabalho já mencionado, por vezes destaca como as reflexões de Adorno e Horkheimer se esforçaram por superar o ponto de vista exclusivamente humano, considerando seriamente a alteridade da natureza, dos animais, e inclusive contribuindo para o nascimento do movimento ecológico alemão (1993, pp. 72-74; 192).
}

SANTOS, João Wilson Sobral. De ninguém a outrem: dialética e mimese, judaísmo e humanismo a partir de Blanchot e Adorno. Griot : Revista de Filosofia, Amargosa - BA, v.21 n.3, p.15-34, outubro, 2021. 
natureza, é mais que a simples natureza, na medida em que se apercebe de sua própria imagem. A emancipação individual e social da dominação é o movimento contrário à falsa projeção, e todo judeu que soubesse vence-la dentro de si perderia toda semelhança com a desgraça que irrompe cegamente sobre ele, assim como todos os perseguidos, homens ou animais. (ADORNO; HORKHEIMER, 2006, p. 164)

A tese VII é um panorama maior acerca da transformação do liberalismo em fascismo, cujo conceito principal talvez seja o de expropriação psicológica: "a irracionalidade da adaptação dócil e aplicada à realidade torna-se, para o indivíduo, mais racional que a razão" (ADORNO; HORKHEIMER, 2006, p. 168). A velha ética protestante que orientava a "pequena empresa psicológica", o homo oeconomicus como engrenagem necessária da economia de mercado, isso se torna obstáculo, superfluidade para o capitalismo tardio em que as grandes corporações se fundem com aparelhos de Estado, procurando sempre a maior racionalidade econômica, isto é, o "menor meio" (ADORNO; HOR KHEIMER, 2006, p. 169).

\begin{abstract}
O progresso da sociedade industrial, que devia ter eliminado como que por encanto a lei da pauperização que ela própria produzira, acaba por destruir a ideia pela qual o todo se justificava: o homem enquanto pessoa, enquanto portador da razão. A dialética do esclarecimento transforma-se objetivamente na loucura. (ADORNO; HORKHEIMER, 2006, p. 168)
\end{abstract}

Tudo se resume a "uma direção das massas que não seja perturbada pela individuação" (ADORNO; HORKHEIMER, 2006, p. 168). Daí a metáfora do ticket. O ticket é a mentalidade requerida por tal direção das massas, a passividade com que se aceita todo um bloco de mecanismos sociais à revelia de qualquer individualidade, espontaneidade, consciência própria. Comprar o ticket é embarcar na expropriação psicológica, na absoluta apatia generalizada: “as associações e as celebridades assumem as funções do ego e do superego, e as massas, despojadas até mesmo da aparência da personalidade, deixam-se modelar muito mais docilmente segundo os modelos e palavras de ordem dadas, do que os instintos pela censura interna" (ADORNO; HORKHEIMER, 2006, p. 167). Para Adorno e Horkheimer, a lógica do ticket se aplica tanto à ideologia fascista, quanto à ideologia comunista, tanto para progressistas, quanto para reacionários, o que só pode significar que a ideologia se normalizou, não como contrabando internacional, mas como pura e simples ditadura da realidade ou mentira a céu aberto. Escolher qualquer ticket "significa adaptar-se a uma aparência petrificada como uma realidade" (ADORNO; HOR KHEIMER, 2006, p. 169).

Esse ticket que transforma os sujeitos em autômatos pressupõe que ao menos seus corpos ainda guardem vestígios humanos e, portanto, também fornece as regras básicas para suas compensações neuróticas e psicóticas: antissemitismo e toda forma de ódio catalogado, ódio contra a diferença. $O$ ticket inclui o manejo do "ressentimento dos sujeitos dominados pela dominação da natureza" (ADORNO; HORKHEIMER, 2006, p. 171), que foi desde o início a abstração do encontro com a diferença; o ticket, no fundo, é a passagem que leva do esclarecimento à violência.

\title{
Nota sobre a interversão
}

O conceito de interversão (umschlagen) é aqui utilizado como apoio teórico, seguindo as considerações de Ruy Fausto em Dialética marxista, humanismo e anti-humanismo. No nível da

SANTOS, João Wilson Sobral. De ninguém a outrem: dialética e mimese, judaísmo e humanismo a partir de Blanchot e Adorno. Griot : Revista de Filosofia, Amargosa - BA, v.21 n.3, p.15-34, outubro, 2021. 
pré-história do homem, que coincide com o nível estrutural do capitalismo, "o homem é e não é". "Ele é somente através de "seus" predicados, que são negações... Porque "pôr" (setzen, poser) o homem, isto é, postular uma prática "humana" (não violência etc.) num universo inumano (o do capitalismo e em geral o de todo o pré-socialismo), implica aceitar - se tornar cumplice d' este universo inumano. O humanismo deve, pois, ser rejeitado" (FAUSTO, 2015, p. 51). Ao que Fausto rapidamente acrescenta: também o anti-humanismo deve ser rejeitado. $O$ contrário dessas posições ou fundações do entendimento será, para ele, a razão dialética, que implica a supressão (aufhebung) ao invés da interversão. ${ }^{15}$

Mas no Capital, não é só o homem, mas toda uma série de pressuposições (no sentido estrutural, não dialético) que sofrem interversão: riqueza, liberdade, propriedade, em geral todas as noções constitutivas da ideologia do capitalismo (FAUSTO, 2015, p. 89). Fausto localiza a interversão no capítulo sétimo do livro primeiro de $O$ capital, a saber, na teoria da reprodução, ou da passagem da acumulação primitiva para a acumulação capitalista. Conforme o resumo de Fausto:

uma volta do capital ou cada volta do capital obedece à lei de apropriação ou de propriedade das economias mercantis, lei segundo a qual a apropriação dos produtos se faz pela troca de equivalentes e depende, em última instância, do trabalho próprio. Mas a repetição das voltas do capital - e portanto o cumprimento reiterado da lei de apropriação pelo trabalho e pela troca de equivalentes - interverte esta lei na lei da apropriação capitalista, apropriação sem equivalente do trabalho alheio. (FAUSTO, 2015, p. 76)

Aquilo que em tese era uma liberdade inicial para a relação de trabalho se torna obrigação de alienar o trabalho para poder sobreviver, aparência de liberdade; a propriedade se torna desapropriação (ou alienação); a riqueza, pauperização, etc.

No nível estrutural, a posição do capitalismo pressupõe o homem, mas homem negado, universal abstrato - é até onde Fausto identifica que vai a análise anti-humanista de Althusser. Para o pensamento dialético, entretanto, essa negação abstrata que, a rigor, é o móbile da interversão, é novamente negada (conservando o homem enquanto pressuposto, mas do ponto de vista de seu vir-a-ser, do ponto de vista do socialismo, para dizer logo tudo) na supressão (desta vez negação determinada), alcançando-se o universal concreto, a reconciliação entre propriedade e trabalho, separados no capitalismo.

Seguindo a pista dada pelo próprio Marx no Prefácio da segunda edição de $O$ Capital, Adorno, Horkheimer e Fausto estão atentos à importância da dialética (e de Hegel) como arma crítica contra a interversão. Ao distinguir pensamento dialético e entendimento em torno da "necessidade de fundação", Fausto acaba dialogando involuntariamente com um dos termos invocados na Tese VI dos Elementos do Antissemitismo, a espera: a aufhebung dialética "se apresenta como uma espécie de "suspensão" do ato de fundar à espera do transcurso do tempo... a dialética põe entre parênteses o ato de fundar para se apropriar teórica e praticamente do mundo" (FAUSTO, 2015, p. 56). Uma espera crítica e não passiva, portanto. Na confluência entre esclarecimento e capitalismo tardio, vê-se a interversão entre luz e trevas, "e se fundar é

\footnotetext{
150 termo aufhebung, que agrega três sentidos (negação, conservação, elevação), oferece dificuldades de tradução. Em nota, Fausto explica que opta por supressão para preservar o sentido da contradição (FAUSTO, 1983, p. 203). Na tradução da Dialética Negativa de Adorno, Marco Antonio Casanova opta por "suspensão" (ADORNO, 2009, p. 21). Já Paulo Meneses, na tradução da Fenomenologia do Espírito de Hegel, obra que consagrou o uso do termo, optou por aglutinar supressão e assunção, formando a palavra "suprassunção" (HEGEL, 2019, p. 7).
}

SANTOS, João Wilson Sobral. De ninguém a outrem: dialética e mimese, judaísmo e humanismo a partir de Blanchot e Adorno. Griot : Revista de Filosofia, Amargosa - BA, v.21 n.3, p.15-34, outubro, 2021. 
clarificar... o máximo de clareza é na realidade obscurecimento" (FAUSTO, 2015, p. 55). É o próprio Fausto, finalmente, em outro lugar, que afirma: “Adorno e Horkheimer desenvolveram, num livro famoso, o tema da "dialética do Aufklärung", o da interversão do iluminismo em mito..." (FAUSTO, 2008, p. 180).

\section{Nota sobre a mimese}

E haveria semelhanças, afinidades eletivas entre mimese e dialética? Os termos em que se formula esta pergunta remetem evidentemente a Goethe e Benjamin (mas por que não também a Wittgenstein?). "Afinidades eletivas", como se sabe, era um termo técnico extraído da química que Goethe utilizou para caracterizar a intriga entre casais de seu romance homônimo. Assim se destacava a mútua interferência entre os reinos da razão e da paixão sob o domínio de uma mesma natureza. Quanto a Benjamin, para além da crítica que fez desse romance, importa notar, junto a muitos comentadores, sua influência na produção madura de Adorno, enquanto escritos da década de 1930 como $A$ doutrina das semelhanças e $A$ capacidade mimética certamente contribuíram para o tratamento da mimese já na Dialética do Esclarecimento. Aí, porém, são agregadas novas referências a essa constelação:

[...] a tendência a perder-se em vez de impor-se ativamente no meio ambiente, a propensão a se largar, a regredir à natureza. Freud denominou-se pulsão de morte, Caillois le mimétisme. Um vício semelhante atravessa tudo o que se opõe ao progresso inflexível, desde o crime, que é um atalho evitando as formas atuais do trabalho, até a obra de arte sublime. A moleza com respeito às coisas, sem a qual não existe arte, não está tão afastada da violência crispada do criminoso. (ADORNO; HORKHEIMER, 2006, p. 187)

Que a mimese é essa tendência à perdição no ambiente, à identificação com o radicalmente outro associado à natureza, já tinha sido marcado por Adorno e Horkheimer nos três ensaios aqui estudados. Igualmente que essa tendência é recalcada pela racionalidade dominadora, refluindo uma mimese da mimese, uma máscara mortuária, que Gagnebin (1993) descreve perspicazmente como "mimese perversa", em que pese o recurso dos autores à paranoia, e não à perversão, como modo de identificação social correspondente a tal racionalidade. Agora surgem três novas referências: a pulsão de morte, o mimetismo e a arte. Esta última não é tanto uma novidade, haja vista aquela ambiguidade ressaltada no canto das sereias. As duas primeiras podem ser rapidamente abordadas com o auxílio das observações de Safatle.

Importa a Safatle, de início, afastar-se de certa interpretação hegemônica da mimese adorniana (reportada à Habermas e Honneth) como retorno a uma natureza originária ou a um "ser" que funcione como fundamento positivo de sentido. Ao invés disso, "sendo a mediação posta como um processo universal, é simplesmente impossível à natureza aparecer como locus do originário ou do arcaico" (SAFATLE, 2005, p. 33). Em Adorno, a natureza funcionaria muito mais como "figura do negativo" (SAFATLE, 2005, p. 33), daquilo que sempre acaba excedendo a pretensão totalitária da razão. Freud e Caillois teriam mostrado duas faces dessa mesma negatividade. ${ }^{16}$ No primeiro caso, a pulsão de morte indica uma inadequação insuperável entre a pulsão e suas metas, de modo a, no limite, levar o indivíduo de volta ao inorgânico. Se a isso

16 Neste parágrafo, segue-se a abordagem de Safatle (2005, pp. 36-38) a respeito dessas duas referências.

SANTOS, João Wilson Sobral. De ninguém a outrem: dialética e mimese, judaísmo e humanismo a partir de Blanchot e Adorno. Griot : Revista de Filosofia, Amargosa - BA, v.21 n.3, p.15-34, outubro, 2021. 
acrescentarmos o comentário de Giacoia sobre o dualismo pulsional freudiano, articulando as pulsões de morte e de vida, entende-se melhor como o recurso adorniano à pulsão de morte, segundo Safatle, intenciona liberar a produção de subjetividades abertas ao não-idêntico que as constitui por dentro e não apenas adequadas a padrões simbólicos identitários ${ }^{17}$. Quanto ao mimetismo em Caillois, trata-se de uma tendência animal à "pura" semelhança espacial, não uma semelhança determinada a algo, embora ela acabe se efetivando de algum modo; aquém de uma atividade de defesa ou de predação, ela é um pathos da semelhança. As referências a Freud e a Caillois são articuladas por Safatle em torno daquilo que Adorno designou na Dialética Negativa como "primado do objeto":

o objeto é aquilo que marca o ponto no qual o eu não reconhece mais sua imagem, ponto no qual o sujeito se vê diante de um sensível que é "materialidade sem imagem", cuja confrontação implica um perpétuo descentramento. A mimesis aparece assim sob o aspecto de reconhecimento de si na opacidade do que só se oferece como negação. (SAFATLE, 2005, p. 38)

Trata-se de insistir na opacidade e na resistência de uma instância objetiva não-idêntica que preserva a negatividade do processo dialético e previne a identidade de qualquer absolutização. Isso também foi mostrado no estudo de Duarte sobre a concepção de domínio da natureza em Adorno. Duarte considera que a dialética entre mímesis e racionalidade só se "resolve" na teoria estética de Adorno (o que, a bem dizer, envolve mais do que apenas a obra póstuma homônima). O domínio da natureza revela uma ambiguidade que consiste na mediação mútua entre arte e natureza (DUARTE, 1993, pp. 16; 61; 66; 133-148; 185-186). Por um lado, a natureza aparece como instância da não-liberdade, obstáculo que deve ser dominado em prol da unidade do Eu; por outro, o Eu não só é obrigado a se constituir pela mediação com tal instância, como também ela é o que inexoravelmente impedirá uma unidade absoluta (ou uma mediação total subjetivo-conceitual-sintética de que Adorno acusa $\mathrm{Hegel}^{18}$ ). O paralelo com a obra de arte, ou aquilo que se poderia chamar de racionalidade mimética (diametralmente oposta à racionalidade instrumental), está na necessidade do tratamento artístico dos materiais. Por isso não há retorno rousseauísta a uma natureza originária, nem compulsão à dominação de uma natureza adversária, mas "composição" 19 com a máxima intensidade possível do sujeito e do objeto em relação, relação, porém, nunca esgotável, mas exorbitante, como também diria Blanchot.

Finalmente, a afirmação da relação entre mimese e dialética é simplesmente o núcleo da argumentação da Introdução da Dialética Negativa. Neste texto, Adorno empreende dois grandes movimentos, entre outros: defender a possibilidade (a "utopia", como chegar a dizer

\footnotetext{
${ }^{17}$ Cf. GIACOIA, 2020. A articulação criativa das pulsões de morte e de vida certamente se distingue da supremacia da pulsão de morte nas dinâmicas suicidas do esclarecimento e do capitalismo. Isso leva a uma ressignificação da morte que convoca Blanchot e se liga ao tema do mimetismo em Caillois. No ensaio $A$ grande recusa, Blanchot critica a noção heideggeriana da morte como derradeira possibilidade da impossibilidade de ser e reivindica para ela a pura impossibilidade ou o "pathos do exterior" como modo radicalmente afirmativo de presença, de ser, de vida (BLANCHOT, 1969, pp. 73-94). A morte se torna a experiência viva de uma "intimidade com o Exterior", o que conversa de perto com o conceito de Caillois e ainda mais com a noção lacaniana de "extimidade" ou exterioridade íntima (cf. Seminário VII, entre outros).

18 “A mediação não significa de maneira alguma que tudo é absorvido nela, mas postula que aquilo por meio do que ela é mediada é algo que não se deixa absorver; a própria imediatidade, porém, representa um momento que não carece do conhecimento, da mediação, como essa mediação carece do imediato... A equivocidade no conceito de mediação - uma equivocidade que exige a equiparação mútua dos polos reciprocamente contrapostos à custa de sua diferença qualitativa da qual absolutamente tudo depende - remonta à abstração" (ADORNO, 1966, p. 149).

19 O sentido de composição é o musical mesmo. Cf. ADORNO, 1966, pp. 142-144.
}

SANTOS, João Wilson Sobral. De ninguém a outrem: dialética e mimese, judaísmo e humanismo a partir de Blanchot e Adorno. Griot : Revista de Filosofia, Amargosa-BA, v.21 n.3, p.15-34, outubro, 2021. 
várias vezes) de uma dialética não identitária e não totalitária, e seu pressuposto, a mediação do conceitual no não-conceitual. Tudo passa pela crítica do idealismo absoluto hegeliano, com seu "primado do sujeito", ao mesmo tempo em que reconhece sua contribuição: "Hegel tinha restituído à filosofia o direito e a capacidade de pensar em termos de conteúdo" (ADORNO, 2009 , p. 14). No interior do próprio sistema hegeliano, a dialética do método expõe sua insuficiência diante da dialética da coisa (ADORNO, 2009, p. 48). A dialética negativa é movimento que, no interior do conceito, apresenta a contradição (real), o não-idêntico, o nãoconceitual, enfim, o mimético, como necessidade e resistência indissolúvel inerente ao próprio conceito. Longe de ser um método aplicado de fora, "seu nome não diz inicialmente senão que os objetos não se dissolvem em seus conceitos" (ADORNO, 2009, p. 12). Adorno procura uma alternativa tanto contra o idealismo/ontologismo, quanto contra o materialismo dogmático: "para a dialética, a imediatidade não permanece aquilo pelo que ela se apresenta imediatamente. Ela se transforma em momento ao invés de ser fundamento" (ADORNO, 2009, p. 41). Portanto, não se trata de mera afirmação da diferença, mas de mediação na diferença. Em Adorno, paradoxalmente, a mimese quer dizer a diferença. Todos esses elementos da mimese compõem uma racionalidade reconciliada com o não-idêntico, com o diferencial e, por isso, capaz de empenhar um novo humanismo bem próximo daquele concebido por Blanchot, afinidade que este artigo pretendeu sustentar. Talvez o trecho abaixo dê conta dessas breves indicações, além de recuperar os temas da Dialética do Esclarecimento abordados neste artigo.

O ideal do diferenciado e nuançado, que o conhecimento nunca esqueceu totalmente até os mais recentes desenvolvimentos, apesar de todo "science is measurement", não se relaciona somente com uma capacidade individual, dispensável para a objetividade. Ele recebe seu impulso da coisa. Diferenciado é aquele que, na coisa em seu conceito, ainda consegue distinguir o mais ínfimo que escapa ao conceito; somente a diferencialidade alcança o mais ínfimo. Em seu postulado, ou seja, no postulado da faculdade da experiência do objeto - e a diferencialidade é a sua experiência transformada em forma de reação subjetiva -, o momento mimético do conhecimento, o memento da afinidade eletiva entre aquele que conhece e aquilo que é conhecido, encontra refúgio. No interior do processo conjunto do esclarecimento, esse momento vai se desfazendo pouco a pouco. Mas esse processo não o afasta totalmente, na medida em que não quer anular a si mesmo. Ainda na concepção de um conhecimento racional, livre de toda afinidade, sobrevive o tatear em direção àquela concordância que outrora era incontestável para a ilusão mágica... o momento mimético se funde por sua parte n curso de sua secularização com o momento racional. Esse processo compreende-se como diferencialidade. $($ ADORNO, 2009, p. 46) 20

\footnotetext{
${ }^{20}$ Agradecimento: ao Prof. Dr. César Kiraly (UFF) e à Sociedade Cética das quintas-feiras.
} 


\section{Referências}

ADORnO, T. Dialética Negativa. Trad. Marco Antonio Casanova. Rio de Janeiro: Zahar, 2009. ADORNO, Theodor; HORKHEIMER, Max. Dialética do esclarecimento: fragmentos filosóficos. Trad. Guido Antonio de Almeida. Rio de Janeiro: Zahar, 2006.

BLANCHOT, M. A conversa infinita 1: a palavra plural. Trad. Aurélio Guerra Neto. São Paulo: Escuta, 2001.

BLANCHOT, M. A conversa infinita 2: a experiência limite. Trad. João Moura Jr. São Paulo: Escuta, 2007.

BLANCHOT, M. A conversa infinita 3: a ausência de livro. Trad. João Moura Jr. São Paulo: Escuta, 2010.

DELEUZE, G.; GUATTARI, F. Mille Plateaux. Paris: Les Éditions de Minuit, 1980.

DUARTE, R. Mímesis e racionalidade: a concepção de domínio da natureza em Theodor W. Adorno. São Paulo: Loyola, 1993.

FAUSTO, R. Dialética marxista, humanismo e anti-humanismo. In: Sentido da dialética: (Marx: lógica e política): tomo I. Petrópolis, RJ: Vozes, 2015.

FAUSTO, R. Em torno da pré-história do totalitarismo igualitarista. In: Revista Lua Nova. São Paulo: 2008, 75, pp. 143-198.

FREUD, S. Moisés e o Monoteísmo. In: Obras completas, volume 19. Trad. Paulo César de Souza. São Paulo: Companhia das Letras, 2018.

GAGNEBIN, J. Do conceito de mímesis no pensamento de Adorno e Benjamin. In: Revista Perspectivas. São Paulo: 1993, v.16, pp. 67-86.

GIACOIA JUNIOR, O. O dualismo pulsional e suas exigências. In: Voluntas: Revista Internacional de Filosofia. Santa Maria, RS: 2020, v. 11, n. 2, pp. 6-22.

MARX, K. Sobre a questão judaica. Trad. Nélio Schneider. São Paulo: Boitempo, 2010.

NIETZSCHE, F. Crepúsculo dos Ídolos. Trad. Paulo César de Souza. São Paulo: Companhia das Letras, 2006.

NIETZSCHE, F. Ecce Homo: como alguém se torna o que se é. Trad. Paulo César de Souza. São Paulo: Companhia das Letras, 1995.

NIETZSCHE, F. A gaia ciência. Trad. Paulo César de Souza. São Paulo: Companhia das Letras, 2009.

PORTER, J. Odysseus and the Wandering Jew: The Dialectic of Jewish Enlightenment in Adorno and Horkheimer. In: Cultural Critique. University of Minnesota Press, Number 74, Winter 2010, pp. 200-213.

SAFATLE, V. Espelhos sem imagens: mimesis e reconhecimento em Lacan e Adorno. In: Trans/Form/Ação. São Paulo: 2005, 28(2), pp. 21-45.

SUSSEKIND, P. O narrador Ulisses. Cadernos Benjaminianos, Número especial, Belo Horizonte: 2013, pp. 177-186.

TEB: tradução ecumênica da Bíblia. São Paulo: Edições Loyola, 1994.

WOTLING, P. La philosophie de l'esprit libre. Paris: Éditions Flamarion, 2008.

Autor(a) para correspondência / Corresponding author: João Wilson Sobral Santos. joaow95@gmail.com 